\title{
開水路乱流内層の渦構造と流速波形の相互関係*
}

\section{CORRELATION BETWEEN VORTICAL STRUCTURE AND VELOCITY SIGNALS IN THE INNER LAYER OF TURBULENT CHANNEL FLOW}

\author{
佐賀 孝徳**・大成博文*** ・渡辺勝利****・斎藤 隆***** \\ By Takanori SAGA, Hirofumi OHNARI, Katsutoshi WATANABE and Takashi SAITOU
}

\begin{abstract}
Coherent structures in the inner layer of turbulent channel flow are investigated using the technique of simultaneous flow visualization/LDV measurement. The flow visualization were done in the streamwise view using fluorescent dye illuminated by a sheet of halogen light. Some new aspects of the correlation between characteristic velocity signals of $U, V$ and the structures of streamwise vortices are inffered from this present experiment. The velocity signals associated with bursting event are formed when the pairs of counterrotating streamwise vortices pass through, which generate near the viscous sublayer and develop away from the wall in the inner layer of turbulent channel flow. Further an evaluation of effectiveness of the VITA technique is done by making direct comparisons with the flow visualization.
\end{abstract}

Keywords: coherent structure, streamwise vortex, VITA technique, bursting, flow visualization

\section{1. 緒 論}

今日, 乱流現象内の秩序構造を認識する方法は, 可視 化法, プルーブ計測法, 数值計算法などに大別される. これらは, 個々に優れた特徵を有し, 秩序構造の解明に 有力な役割を果たしてきたが，互いにそれぞれの結果を 整合し得る段階までの発展には至っていない1). 特に, 前 2 者に関しては, 従来よりよく用いられてきた手法で あるにもかかわらず, その長・短所がほぼ相反し合うこ とから，互いの結果が相容れなくなってしまうこともこ れまでには少なくないとされている(1).4). そこで, 両者 の短所を相補し, 長所を生かす手法の確立が非常に重要 であり ${ }^{5)}$, 本論においては, その適用の 1 つとして可視 化とプルーブ計測の同時併用が試みられた。

* 本研究は, 第 30 回水理講演会および第 18 回乱流シン ポジゥムで発表した内容 ${ }^{2), 3)}$ に，その後新たなデータ を加えて考察を重ね, さらに系統的に発展させたもの である.

** 正会員 徳山工業高等専門学校助教授 土木建築工学 科（ 745 徳山市久米高城 3538）

*** 正会員 工博 徳山工業高等専門学校助教授 土木建 築工学科 (同上)

**** 正会員 工修 徳山工業高等専門学校助手 土木建築 工学科 (同上)

***** 正会員 工博 山口大学教授 工学部建設工学科 （テ755 宇部市常般台 2557）
すでに, 乱流境界層においてこの種の実験が, スモー クワイヤー法と熱線流速計を併用して, Head ら ${ }^{6)}$, $\mathrm{Falco}^{7), 8)}$ などによって試みられている. なかでも Falco は, 乱流境界層の外層に 'typical eddies'とよばれる 秩序構造が存在することを見出し, それが, 壁近くに降 下して 'pocket'を形成する要因となり，同時に瞬間的 な高レイノルズ応力の発生を誘起させることを明らかに している. また，Bogard ら ${ }^{9)}$ は, 矩形管流れにおける 熱膜流速計と色素注入法の同時併用実験によって, 従来 の条件付検出法の問題点を比較検討し, 特に, 最適な条 件付検出法を決める際に可視化の結果との対応を明らか にしておくことが重要であることを指摘した.

ところが，このような重要な解明の試みもどちらかと いえば流速波形の解析に重点が置かれており, 著者らの 判断するかぎり, 瞬間的な流速波形に詳細に対応する可 視化の形象をもとにした十分な考察は,これまでに得ら れていないように思われる。

一方, 著者らは, 可視化法を用いて開水路乱流内層に 形成された鱗形状や low speed streak などの重要な秩 序構造の三次元的特徵を詳細に解明し ${ }^{10)}{ }^{111}$, さらにそれ らが bursting 波形 ${ }^{12)}$ や瞬間高レイノルズ応力の発生な よ゙に関係することを明らかにしてきた ${ }^{13)}$. また, 蛍光染 料注入法による横断面可視化によって, 鱗形状や low 
speed streak に関係する「壁縦渦（OSS 渦）」の存在を 明らかにし，さらにその三次元的スケールや流れ方向の 傾斜角, 配置特性などについて詳細に考察した ${ }^{14), 15)}$. し かし, 壁縦洞構造と流速波形の相互関係は不明のままで あり, それを明らかにすることが, 乱れの発生機構やそ れを担う秩序構造の三次元構造を解明するうえできわめ て重要と思われる.

以上を踏まえながら本研究では, 開水路乱流内層にお いて蛍光染料注入法を用いた横断面視とレーザー流速計 測の同時併用が行われ，壁縦渦と瞬間的な流速変動波形 の対応が詳細に考察された。また, 壁繸渦とVITA 法 による条件付検出波形の対応も詳しく検討され,さらに, VITA 法自身の問題点についても考察が加えられた.

\section{2. 実験方法および実験条件}

実験には, 長さ $10 \mathrm{~m}$, 幅 $60 \mathrm{~cm}$, 深さ $15 \mathrm{~cm}$ の総ア クリル製開水路が用いられた。水路勾配は $1 / 500$ に設定 され，上流端には整流装置（径 $4 \mathrm{~mm}$, 長さ $3.2 \mathrm{~cm}$, 幅 $60 \mathrm{~cm}$ の八ニカム), 下流端には水位調整用の堰が設け られた。この水路の上流端から $5.5 \mathrm{~m}$ 下流付近で, 横 断面可視化と流速計測の同時併用実験が Fig. 1 に示すよ うに行われ, 壁近くの維渦の挙動之流速波形 $(U, V$ 成 分）の両方が連続的に対応した情報として得られるよう に工夫された. 可視化法には, 蛍光染料注入法による横 断面可視化が採用された。 その詳細については前報14)に 示されており,ここでは省略する.

流速計測には前方散乱方式のレーザー流速計が用いら れた．計測中はレーザーの出力を最大（2W）にし，蛍 光染料か流速計測点に侵入することによる出力波形のド ロップアウトを可能な限り防ぐことにした。

以上の計測システムを採用することによって，低流速 の波形を精度よくしかも可視化形象を乱すことなく測定 することが可能となった.

可視化の形象と流速波形の対応は，レーザー光線を瞬 間的に遮断して波形の出力を停止させ, そのときの画像

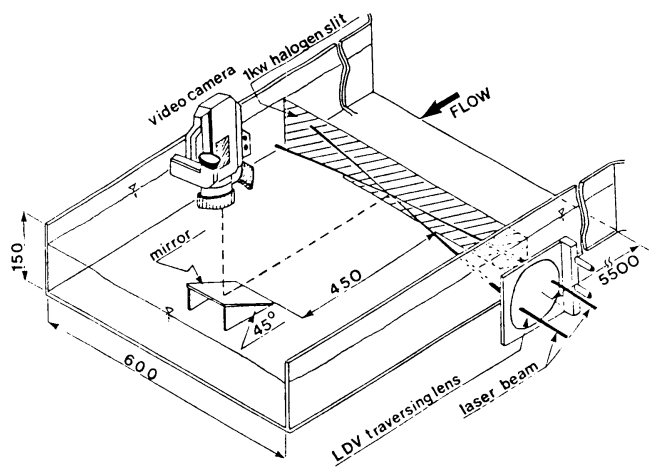

Fig.1 Experimental apparatus.
の時刻を読み取ることによって明確にされた。さうに， モニターテレビおよびシンクロスコープの両方におい て, 鮮明な可視化画像と正常な流速波形が得られ続けて いることが確認された．流速計測点には, 壁縦渦の形成 領域 ${ }^{14)}$ を考虑して $U$ 成分において $y^{+}=30, V$ 成分にお いて $y^{+}=100$ が選ばれた。撮影および計測が 2 回繰り 返され，その時間はいずれも約 240 秒であった。

実験条件は，Table1に示されるとおりであり，壁縦 渦の実寸を可能な限り大きくし, 鮮明な可視化画像が得 られるような流れ場が設定された。また，摩擦速度 $u_{\tau}$ は平均流速分布上り求められた。

Table 1 Experimental conditions.

\begin{tabular}{|c|c|c|c|c|c|}
\hline Case & $\mathrm{Um}(\mathrm{cm}$ & $\mathrm{U}_{\tau}\left(\mathrm{cm} \mathrm{m}_{\mathrm{s}}\right)$ & $H(\mathrm{~cm})$ & $\mathrm{Re} \mathrm{U}_{\text {(Inax }}$ & $R_{\theta}{ }^{(\max }$ \\
\hline A & 7.56 & 0.42 & 10.8 & 9475 & 640 \\
\hline B & 4.75 & 0.29 & 6.62 & 3660 & 351 \\
\hline $\operatorname{Kim}^{12)}$ & 7.62 & 0.36 & $7.87=\delta$ & 5550 & 666 \\
\hline
\end{tabular}

\section{3. 実 験 結果}

\section{（1）壁縦渦と流速変動の対応を考察する視点}

壁縦渦と流速変動との対応を考察する際に，以下の視 点を踏まえることが重要と思われる.

壁縦渦は, 内層に形成されたきわめて重要な秩序構造 の 1 つであり ${ }^{14)}$, それが壁近くの流速変動の形成に重要 な役割を果たしていると思われる.そこで，まず第 1 に， 壁縦渦と流速計測点との相対的位置関係に注目しなが ら, 壁縦渦の横断面形象と流速波形の相互関係を 1 対 1 の対応で識別することである.

第 2 は, 壁緃渦の三次元的挙動と流速変動の相互関係 を明らかにすることである。

第 3 は，第 1 , 第 2 の結果を踏まえながら従来の平面 視による同時併用の結果との整合性について検討するこ とである.

第 4 は, 上記の 3 つの視点を踏まえながら, VITA 法 によって流速波形を条件付検出し，その検出波形と可視 化の形象との対応を詳しく考察することによって VITA 法の利点および問題点を明らかにすることである.

\section{（2）壁綎渦と流速变動との対応}

Fig. 2 は, 壁近くに形成された壁緹渦の横断面可視化 写真の一例である. 壁䋛渦は, 粘性底層に付根を持って 個々の渦が, 常に対で形成され, 固有の三次元的スケー ルと流れ方向傾斜角をもつへアピン型の渦構造であ $3^{14)}$. 壁縦渦の三次元的挙動や相互作用, 複合などによっ て壁近くにさまざまな 2 次流れが誘起されることから， これらの運動が流速変動場の形成にきわめて重要な影響 を与え得ると考えられる. 以下, 壁縦渦の横断面形象之 流速波形の対応を詳察する. 


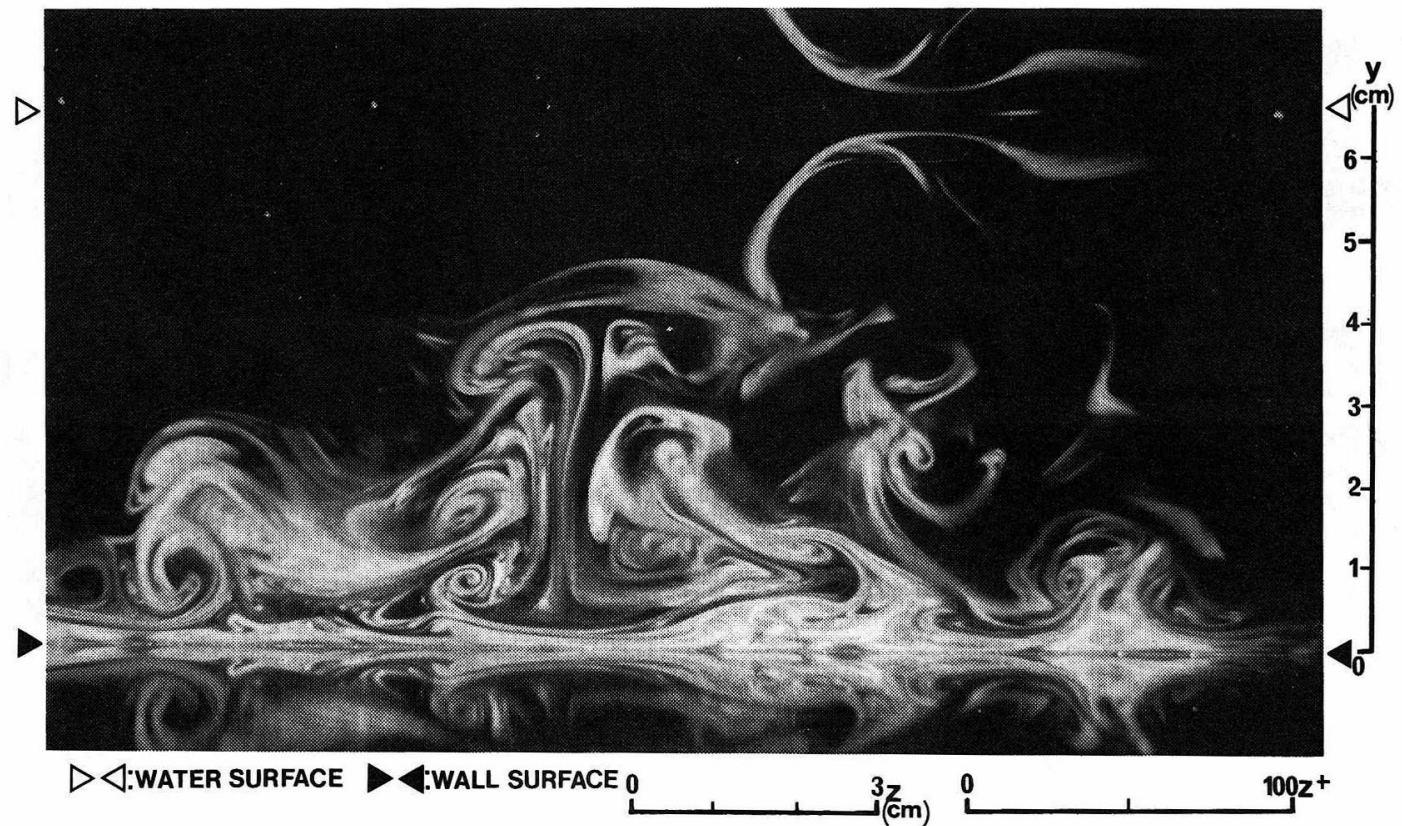

Fig. 2 Streamwise vortices in the inner layer (Case B).

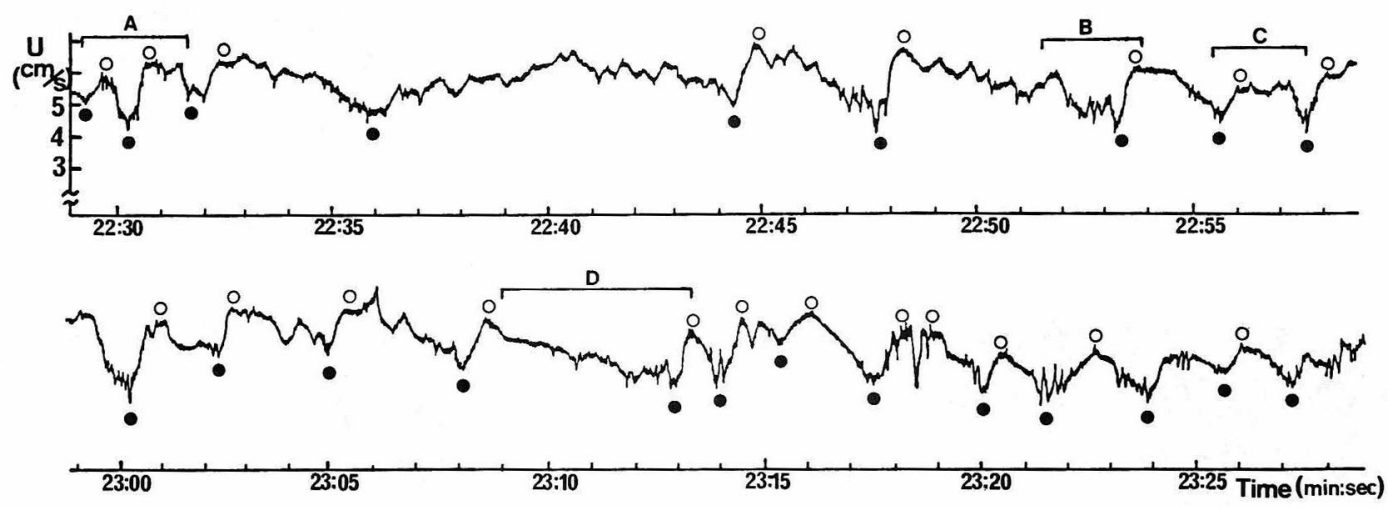

Fig. $3 U$-velocity signals (Case A, $y^{+}=30$ ).

Fig. 3 には, $y^{+}=30$ における流れ方向の流速変動波 形が示されている.この変動波形には, 壁乱流特有の緩 やかに減速した後に急激に加速する，いわゆる bursting 波形 ${ }^{12)}$ が認められる(たとえば波形 $\left.\mathrm{B}, \mathrm{D}\right)$. また，比較 的短周期の急激な変動を示すスパイク型の波形も注目さ れた (波形 A, C). Fig. 4 には，それらの代表的な波形 (波形 $A \sim D$ ) とそれに対応する壁縦渦の横断面写真お よびそのトレースが示されている. 写真下部の数字には 最小単位 0.01 秒のストップウォッチの時刻が示されて おり，この時刻と波形に示された時刻とが対応する.そ して, これらの 3 者に対応する番号が, 写真, トレース, 波形のそれぞれに示されている. また, 時刻を表わす数 字の上部に位置する白い横線が底壁面であり,その上の
細い白い横線が $y^{+}=30$ に挿入されたレーザー光線であ る. 流速計測点は, 白く映るビームと 印を結ぶ線の 交点（トレースでは○印点）に位置している．Fig. 5 に は, 壁縦渦と流速計測点との相対的位置関係を説明する 際に必要な壁縦渦の横断面形象の領域区分が示されてい る. 図中の L 領域は壁縦渦の付根の領域であり, M領域 はL領域上部の壁縦渦の左右の渦に挟まれた中央部分で あるＮＮ領域は，壁縦渦の両端の領域である.

波形 A (写真(1)～(6)）は, 低速, 高速を繰り返すスパ イク型の速度変動である. 写真(1)では, 小さな壁縦渦の M領域に計測点が存在し, そのときの波形は低速を示し ている. (2)では, 計測点の左側で高速流体が入り込み, それに伴って壁縦渦が左側へ摇動しながら計測点を外れ 

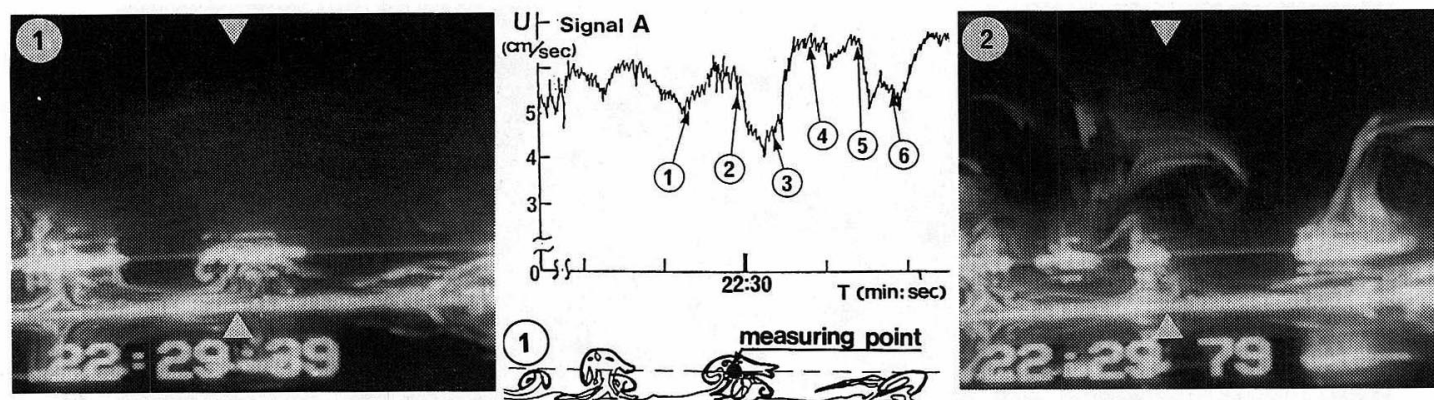

(1) measuring point
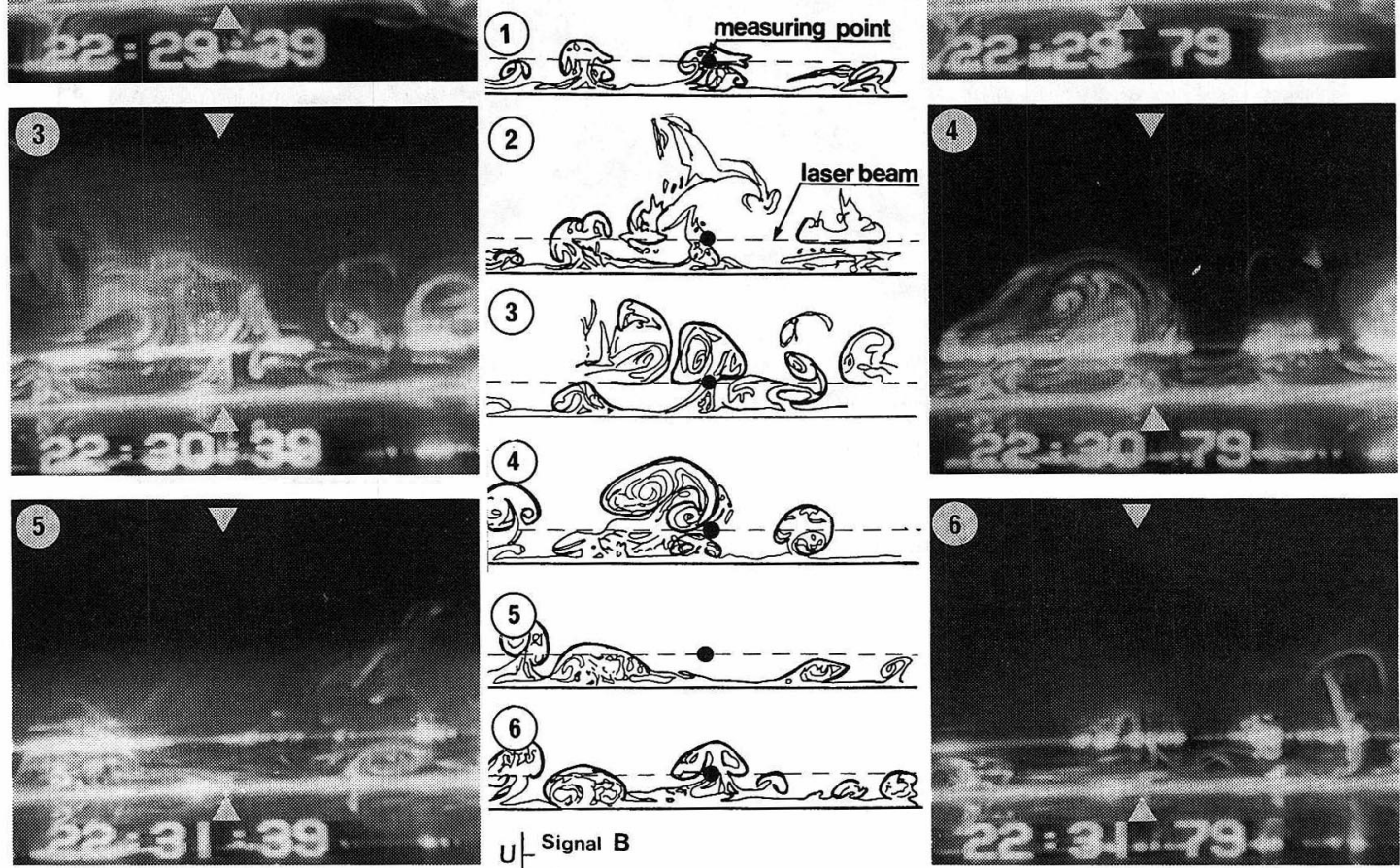

6

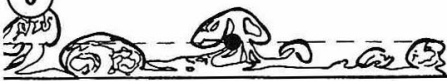
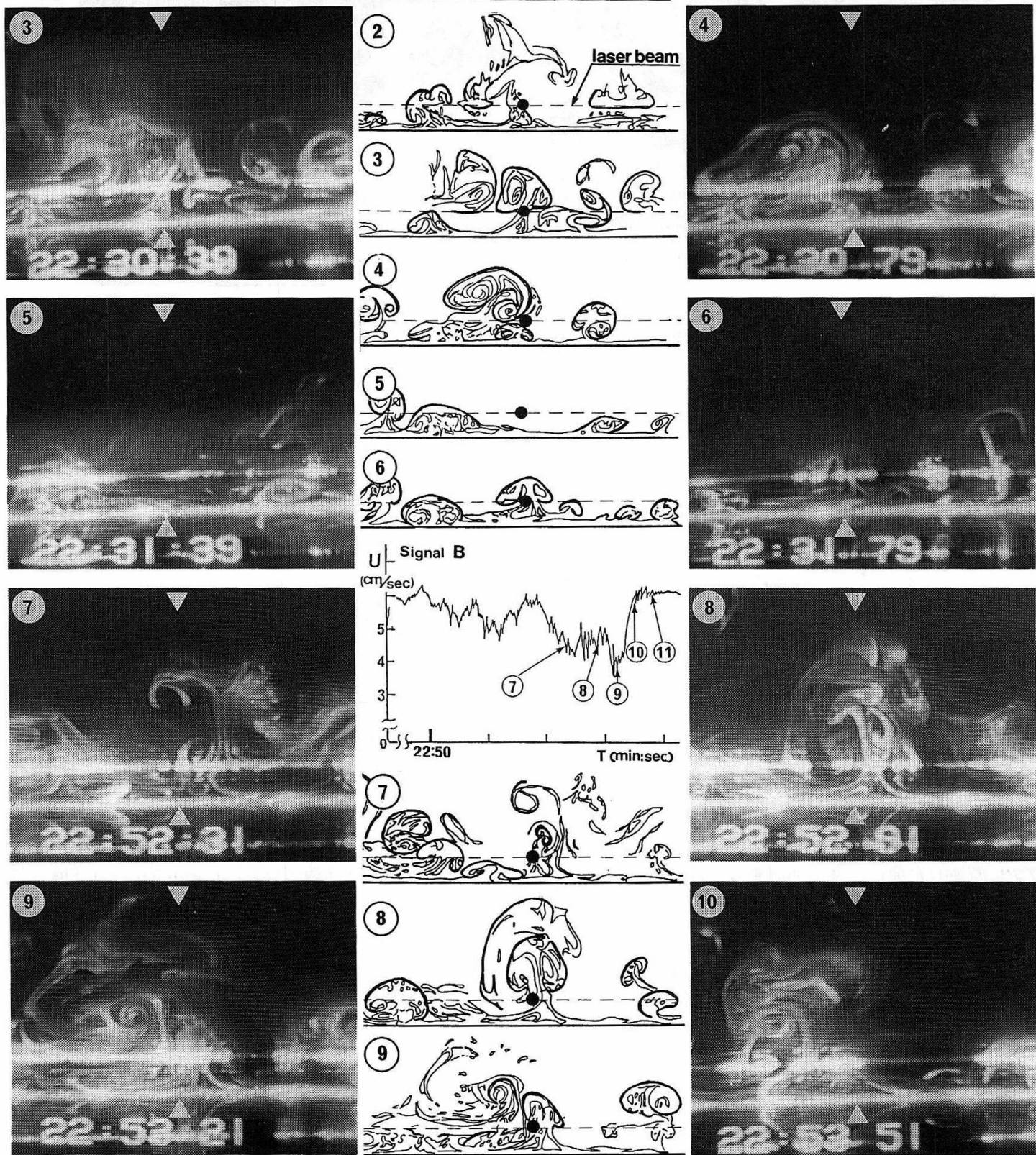

(8)

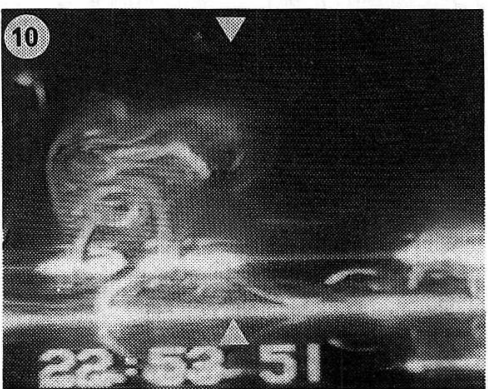



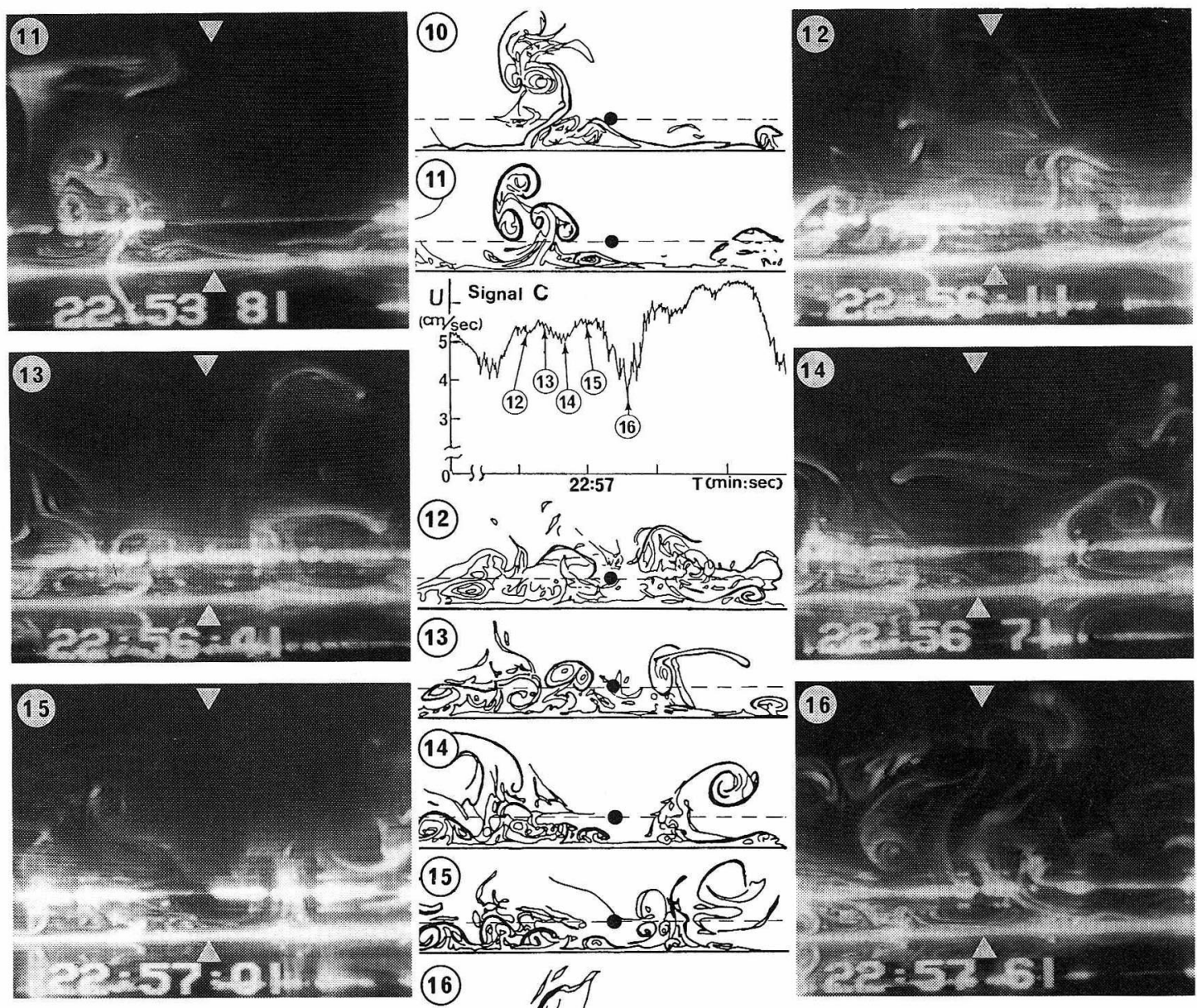
(14)
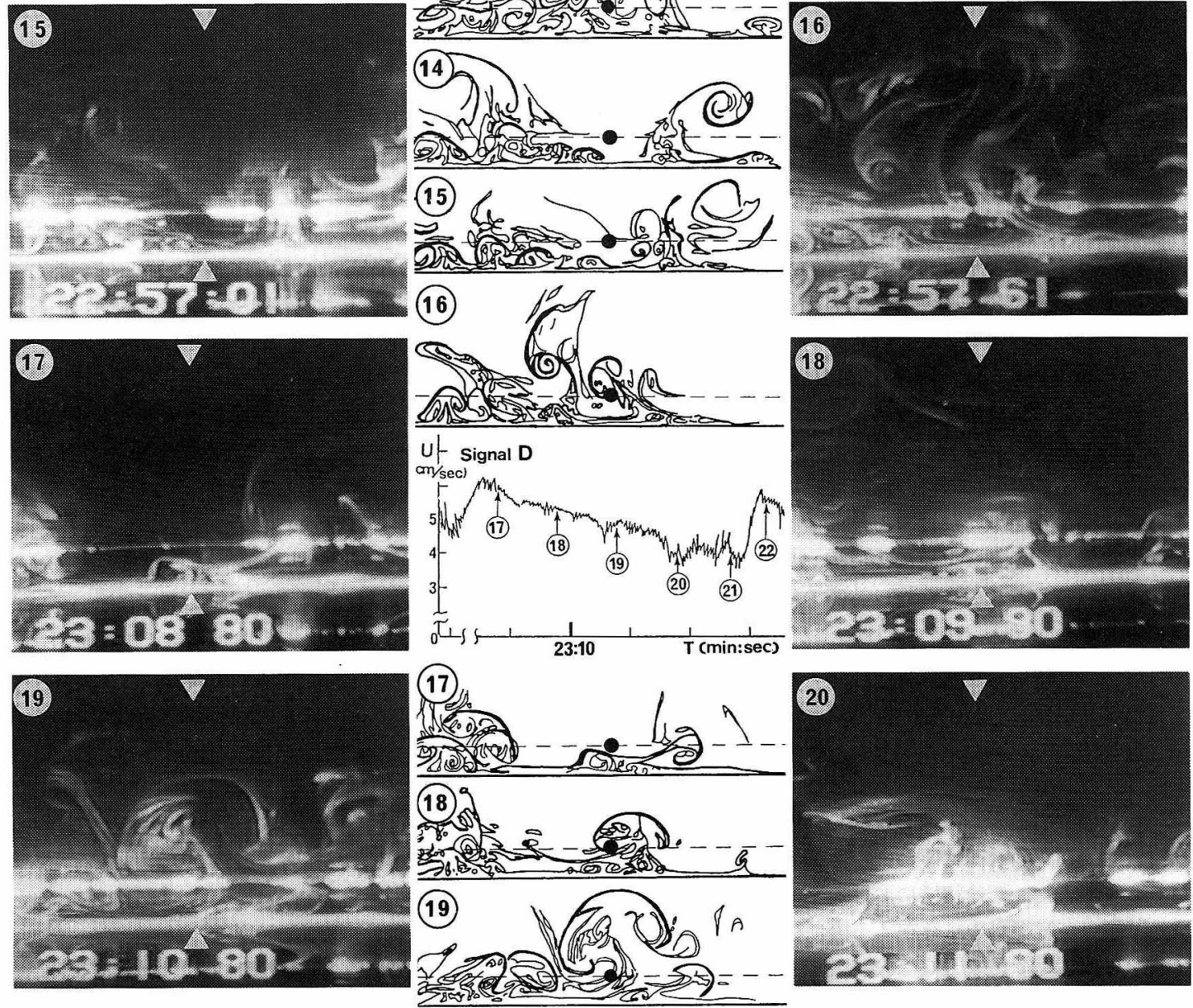

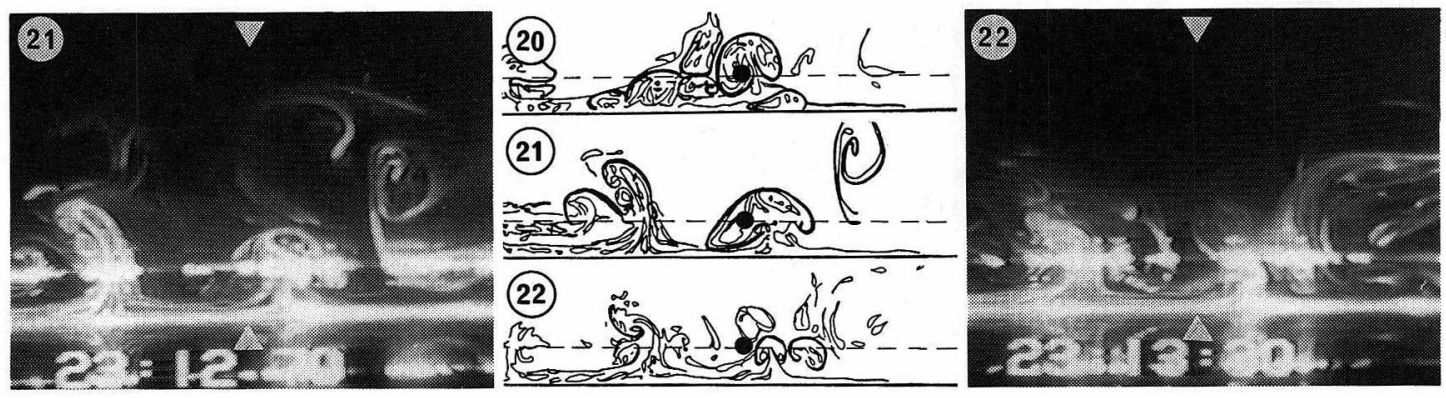

Fig. 4 Simultaneous pictures of streamwise vortices and $U$-velocity signals (Case A).

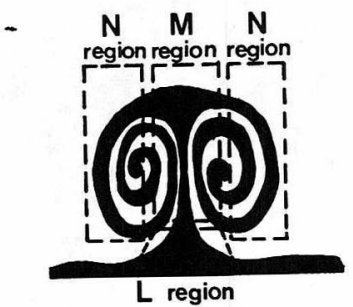

Fig. 5 Individual regions of a streamwise vortex.

ており，そのときに高速の波形が出現している，逆に， (3)では計測点に壁縦渦の L領域が位置し，流速は低速に 向かっている. さらに(4)では, 計測点よりも右側に入り 込んだ高速流体が横方向に広がり, (3)で計測点に位置し た壁縦渦を左に摇動させている. (5)では，その運動がさ らに進行して高速波形が維持されているのが明らかであ る. (6)では，新たに壁縦渦が計測点上に発生し，それに 伴って減速波形が生じていることが認められる.これら の(1)から(5)の一連の低・高速を交互に繰り返す挙動は, 壁維渦と高速流体塊の相互作用のもとで壁縦渦自身が左 右に摇動することによって形成されたものと思われる.

波形 $\mathrm{B}$ (写真(7) (11)）は，比較的高周波数成分を伴っ た低速状態から急激に加速する速度変動を示している。

(7)の形象では, 小さな壁縱渦の付根（L領域）に計測点 が位置している．この縦渦対は時間の経過とともにさら に小さくなるが, (8)では新たな壁縦渦が計測点に進入し， それが徐々に縮小して(9)に示す状態まで低速が維持され ている. ところが, (10ではその壁綐渦が横に押されて計 測点からはずれ，低速から高速へと波形が変化し，(11)で は高速状態が維持されている．これらのことより，計測 点が 2 つの壁緹渦のL領域を連続して通過することによ り比較的長期間の低速状態が維持されていることが明ら かである. また，低速状態における比較的高周波数成分 は, 計測点が壁縦渦中に存在する際に検出された.

波形C (写真12)（16)）は，高速状態が比較的維持され， それに続きスパイク型の波形が生じているパターンを示 している. 高速がほぼ一定に維持されはじめるのは(12)か
らであり，(13)～(15)と進むに従って高速流体塊がより壁近 くまで到達して, さらにそれが壁に衝突することによっ て流体が横方向に広がり, 左右の壁縦渦の発達が促され ているようである. 特に, (13)では上方からの高速流体の 進入を示す渦形象が計測点上によくみられ, (12) (15)では, 高速の波形が維持されている. ところが，16において計 測点の右側の壁縦渦（15）が計測点方向に摇動し, 計測 点上にそのL領域が来ることによって減速され低速の波 形が形成されたように思われる.これは，摇動現象の一 形態と考えられ，A波形と同時に高速流体の進入と密接 な関係があることも同時に示唆しているように思われ る.

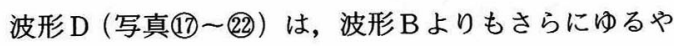
かに減速し，そして急に加速されるパターンを示してい る.この波形の周期は, 約 4.5 秒であるが, これを Burst 周期とみなして外層スケール表示すると $T_{B} U_{\max } / H=3.2$ となり, これは中川らの開水路乱流で 得られた結果 $\left(T_{B} U_{\max } / H=1.5 \sim 3.0\right)^{15)}$ とほぼ一致す る. この減速区間において, 矢印に対応する 5 枚の写真 が示されたが, それぞれ，いずれも壁縦渦の L, M領域 が常に計測点付近に連続して形成され，減速化をそれら が引き継いでいるようである. 重要と思われる点は, 単 独の壁縦渦がこのような長周期の減速を引き起こしたの ではなく，数個のそれが次々と減速に寄与していること である．また(20，(21)では，波形 Bの場合と同様に計測点 が渦中にあり，より高周波数成分が顕著に形成されてい ることが明らかである，最後の(22)では，高速流体の進入 によって計測点上の壁維渦が右方向に摇動し, 計測点を 外れると同時に急激に加速され，高速の波形を形成して いる.

以上の対応を踏まえながら, 壁縦渦の空間構造と流速 変動の相互関係をより詳細に考察する.

すでに著者らは，本実験と同様な流れ場において壁縦 渦の横断面形象の流れ方向の維持時間 $T^{+}$が, 約 90 程 度であり ${ }^{16)}$, この範囲では, Taylor の仮説が成り立つ ことを明らかにしている. そこで, 0.1 秒ごとのビデオ 


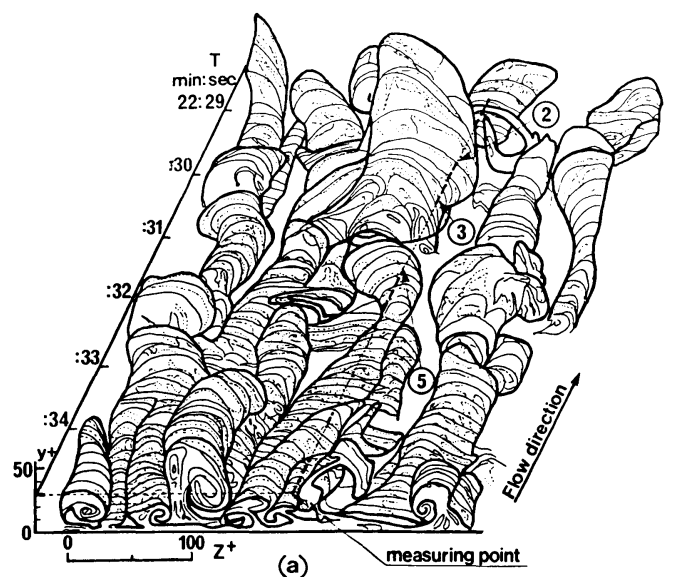

(a)

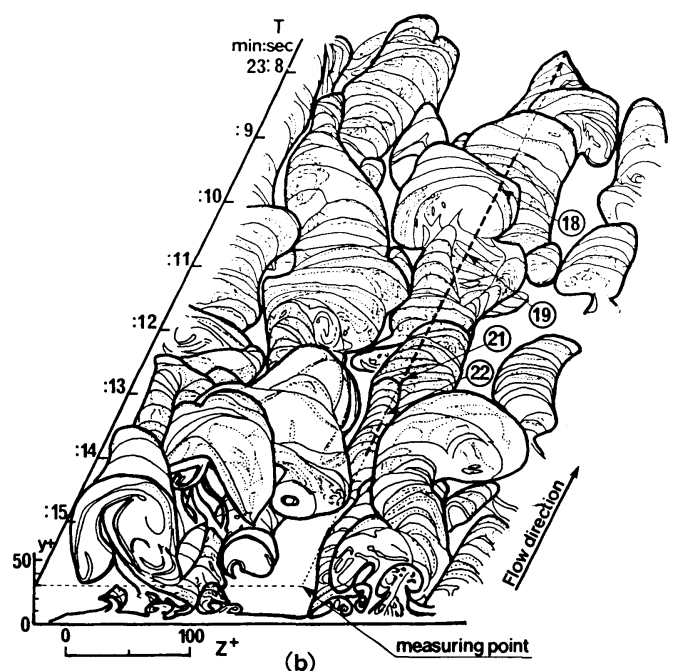

(b)

Fig. 6 Correlation between three dimensional structure of streamwise vortices and measuring point (Case A).

画像間に Taylor の仮説を適用し，それを連ねることに よって得られた壁縦渦の三次元構造図が Fig. 6 に示され ている.

壁縦渦には, 横方向および流れ方向に配置特性 ${ }^{14)}$ が存 在することから，流速波形も壁縦渦群のそれに大きく传 存すると考えられる. Fig. 6 からも明らかなように, 壁 縦渦は流れ方向に連続して発生し, 横方向には相互作用 を伴いながら複合して大規模化を遂げるものも存在して いる.Fig. 6(a)に示された波形 A の摇動パターンは, ちょ うど流れ方向に連なった壁縦渦の周辺部が計測点を通過 した場合といえ, 計測点が壁縦渦内を出入りする様子(細 点線および太点線で区別）が明らかである．Fig.6(b) には, 同様にして描かれた壁縦渦の三次元構造と計測点 の時間軸の位置が示されている.この場合計測点は流れ

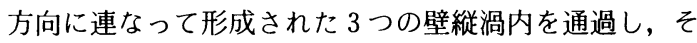
の後壁縦渦の形成されていない相対的高速領域へと抜け 出していることがより一層明らかである. この計測点が わずかに左右に移動し壁縦渦の周辺付近を通過すると上 述の波形 Aに類似したパターンが出現し, さらに, 壁縦 渦が存在しない領域 (細点線) では, 相対的に高速を伴 う波形が連続して形成されることが推測され得る.

以上のことから, 壁縦渦の三次元構造と配置特性が, 流速変動波形の形成に重要な寄与をなすことが明らかで ある。

$V$ 成分波形 $\left(y^{+}=100\right)$ の同時併用の結果が, Fig. 7 に示されている.グラフの縦軸は, 底壁より水表面に向 かう方向を正とした鉛直速度成分であり，横軸は時間を 表わす. 写真下部の数字には, 最小単位 0.01 秒のストッ プウォッチの時刻が示されており，それぞれの波形の時 刻に対応している．時刻上の白い横線が底壁面であり，
その上の 2 本のクロスした横線が $y^{+}=100$ に挿入され たレーザー光線である. 流速計測点はこのクロス点上に あり，その点の上下には】印が記されている.

(23)は, クロス点に上方から高速流体が降下してきた ときが示されており, 下降流を示す負の流速波形が形成 されている. (24), (25)では, 反対に壁近くから壁縦渦が発 生してクロス点まで頭をもたげてきた場合であり, 正の 高速波形が形成された。 そして, (26では再び高速流体塊 がくさび上に進入して, 下降流を示す負の流速波形が形 成されている. また，これ以外についても $V$ 成分波形 と壁縦渦との同様の対応が多く確認された。

以上のように, 上昇流を形成する壁縦渦の L 領域と $\mathrm{M}$ 領域では, 低速波形に対応しており, 壁縦渦の摇動など により, 計測点上に上昇流がなくなる場合や下降流が新 たに形成される場合では高速波形が出現している：上記 4 波形のほかに, Fig. 3 の○, ○印で示された急激な変 動を示す波形に関して同様の可視化との対応が調べら れ，そのすべてにおいて壁縦渦が重要な役割を果たして いることが明らかとなった。

次に，本結果と従来の平面視による同時併用結果 ${ }^{13)}$ と の整合性を若干考察する. 平面視の結果によれば, 低速 の波形は, low speed streak の通過によって形成され る $^{13)}$ が，この壁近くの low speed streak の断面形象は, 壁縦渦のLおよびM領域とほぼ一致しているように思わ れる.また, 高速波形の形成は, 鱗形状の通過や low speed streak の抜け出しの際に実現されている ${ }^{13)}$ が，こ れは壁から離れた高速流体塊が壁近くに到達し, 計測点 から壁縦渦が外れる挙動と対応しているように思われ る. 鱗形状は, 粘性底層上端付近に形成された平面形象 であり, 中央部は高速流体の進入によって陥没し，その 

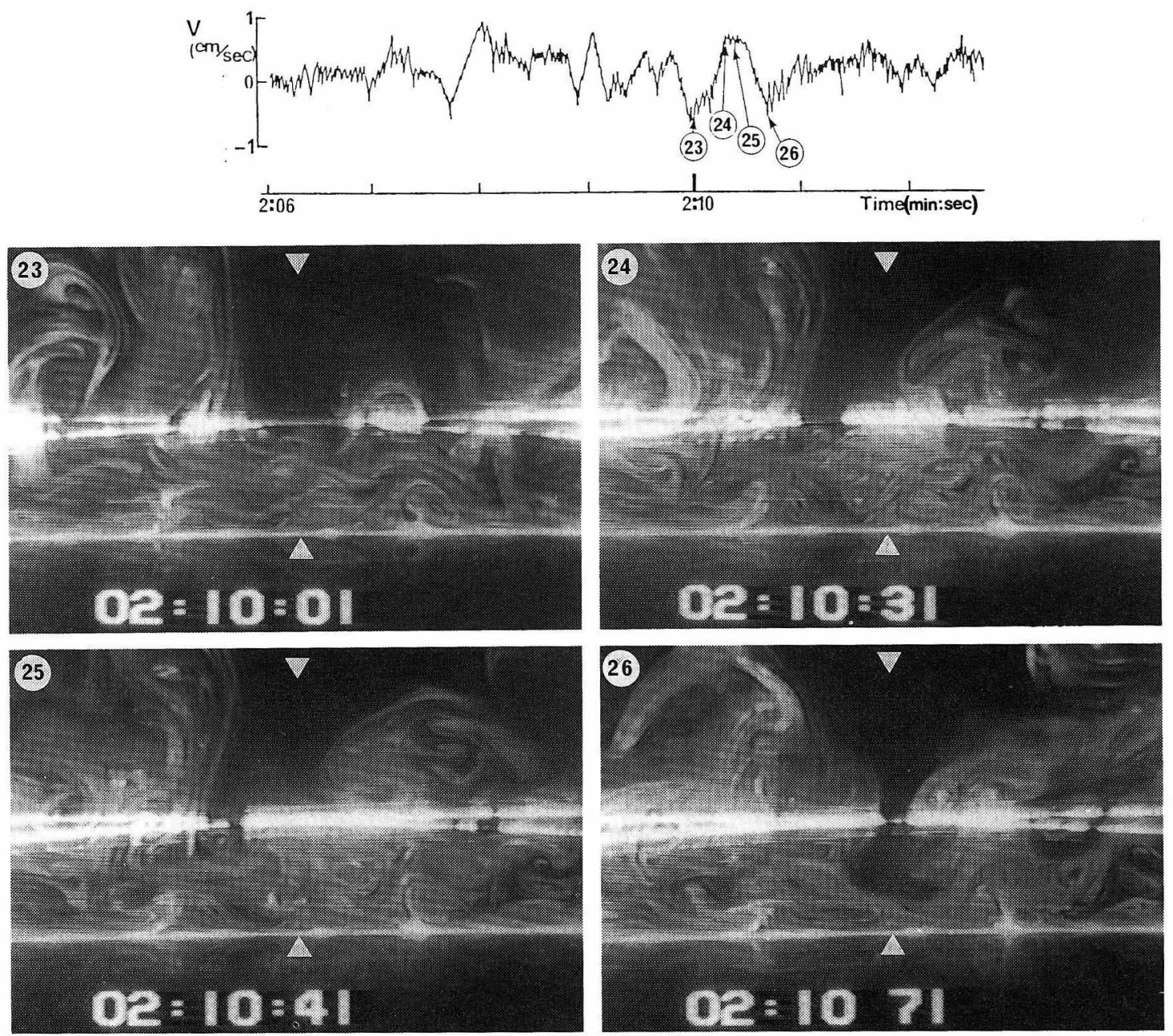

Fig. 7 Simaltaneous pictures of streamwise vortices and $V$-velocity signals (Case A).

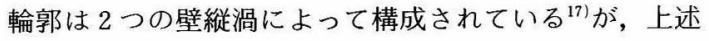
の(12) 一 (16)の過程は, 鱗形状が可視化面を通過する際の断 面形象亡相対的高速波形の通過周期において類似の傾向 を示している.また, low speed streak の抜け出しは, たとえば(21)から(22)に向かう過程が相当しているように思 われる.

以上の考察を包括的に踏まえ, Fig. 8 に示されるよう な壁乱流内層の概念渦モデルが作成された.これにより, 壁縦渦と流速計測点の相対的位置関係によって, それぞ れ異なる流速変動波形の形成される機構が明らかであ り, 図中の細点線および太点線は, それぞれ壁縦渦の外 および中を計測点が通過した場合の軌跡に相当する.

\section{（３）壁縦渦とVITA 法による検出波形の検討}

VITA 法は, bursting 現象の通過に伴って発生する特 徵的な速度波形を計測波形から条件検出しようとする手 法である ${ }^{18)}$. この手法の最も重大な問題点は, 最適な平

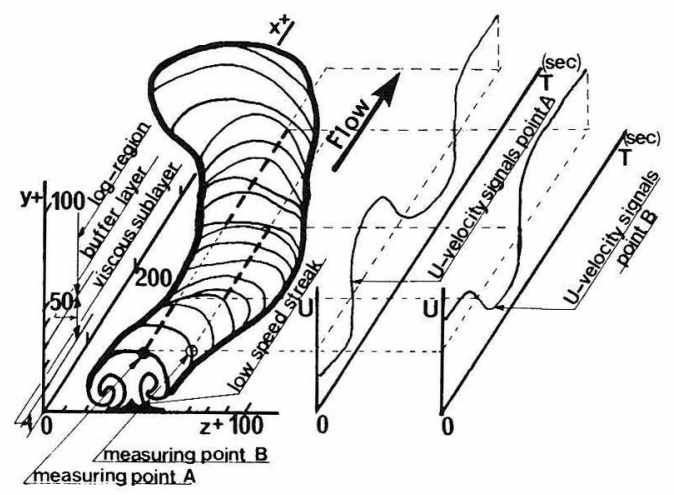

Fig. 8 Conceptual model of vortical structure.

均時間 $T^{+}$としきい值 $k$ をどのように決めればよいか の基準が存在しないことである. そこで，U成分の流 速波形に $T^{+}$, および $k$ を変化させて条件付検出し, 得 
られた波形と壁縦渦との相互関係が検討された。

Fig. 9 には，条件付検出された波形と可視化の対応の 可否に関する確率分布が示されている. 縦軸は, それぞ れ $P(R)=\beta / \alpha, P(F)(A)=\bar{\beta} / \gamma, P(F)(B)=\tilde{\beta} / \gamma$ で表 わされる.ただし， $\alpha$ は可視化と原波形との対応が確認 された総数, $\beta$ は, 可視化と対忘のとれる条件付検出波 形の数, $\bar{\beta}$ は可視化亡対応のとれない条件付検出波形の 数, $\tilde{\beta}$ は複数の変動波形を単一のものとしてエラ一検出 した数, そして $\gamma$ は条件付検出波形の総数であり, $\gamma=$ $\beta+\bar{\beta}+\tilde{\beta}$ となる，横軸はしきい值 $k$ であり， $T^{+}$は 6.5 から 26 まで 4 種類変えられた.この図より $P(R)$ が最 も大きくかつ $P(F)$ が最も小さい場合が, VITA 法に とって最適なパラメーター $k, T^{+}$として選択され得る. 平均時間 $T^{+}=6.5$ では, しきい值 $k$ が小さくなるに つれて, $P(R)$ の值が増加するが, $k=0.4$ 以下ではそ れに伴って $P(F)$ (A) の值も増加している. $T^{+}=13$ では, $k$ の値とはほぼ無関係に, $P(R)$ が $60 \sim 80 \%$ の高い值 を示し, $k=0.8$ で最頻値を得ている. また, $P(F)(A)$, (B) は, $k=0.6$ 以下で増加が認められる. また， $T^{+}=$ 19.5 の場合においても同様に， $k=0.8$ で最頻值が出現 するが, 同時に $P(F)$ (A) もより高い值を示している. そして, $k$ の減少とともに $P(F)$ B のより高い值も出 現している. $T^{+}=26$ では, $P(R)$ のピーク值を含めて 全体が小さくなり， $k$ の減少とともに $P(F)$ B の值が より増加している.

これらのことより, $P(R)$ が最も大きく, しかも $P(F)$ (A), (B) が最も小さい最適な条件は, $T^{+}=13$ および $k=$ 0.8 である.これは, 最近 Bogard ら ${ }^{9}$ が用いた $T^{+}=14$

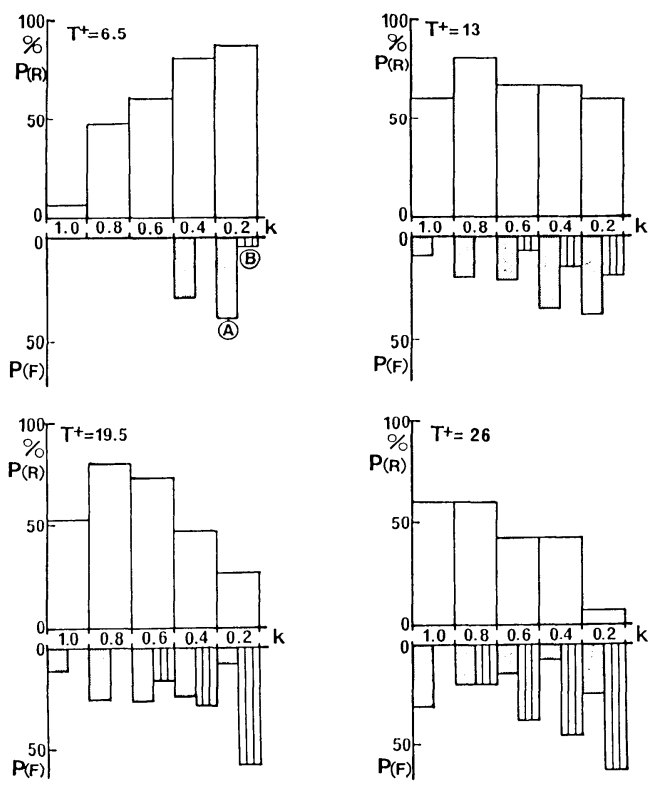

Fig. 9 Histogram of $P(R)$ and $P(F)$.
および $k=1.0$ の值と大きな差異はないように思われ る.

さらに， $T^{+}$および $k$ と Burst 周期の相互関係を明ら かにするために，Fig.10が描かれた。横軸には，しき い值 $k$, 縦軸には Burst 周期がそれぞれ示されている. 図中のシンボル OS は,それぞれの $T^{+}$および $k$ にお いて条件付検出された波形の平均周期を表わし，また CS は, OS の中で可視化と対応した波形のみの平均周 期に相当する. また，原波形において壁縦渦と関係づけ られたすべての波形の平均周期が破線 $\mathrm{S}_{\mathrm{T}}$ で示されてい る.この值は, 中川らによって計測された Burst 周期の 値と ${ }^{15)}$ 一致している.

この図より，CS が，OS と最も接近し，さらに $\mathrm{S}_{\mathrm{T}}$ に 最も近い值を示すときの $T^{+}$および $k$ が最適パラメー タ一と考えられることから, それらの值として $T^{+}=13$, $k=0.8$ が得られた.これは，当然のことながら Fig. 9 の結果とも一致する.

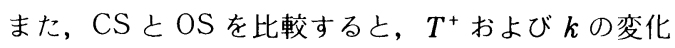
に応じて, CS は大きく変化するが, 逆に OS は全体と して $\mathrm{S}_{\mathrm{T}}$ 值付近に分布している.このことは, 上述の最 適パラメーターの決定方法が重要であり, OS のみでは 壁縦渦と無関係の変動波形をエラ一検出する場合がある ことを示している.

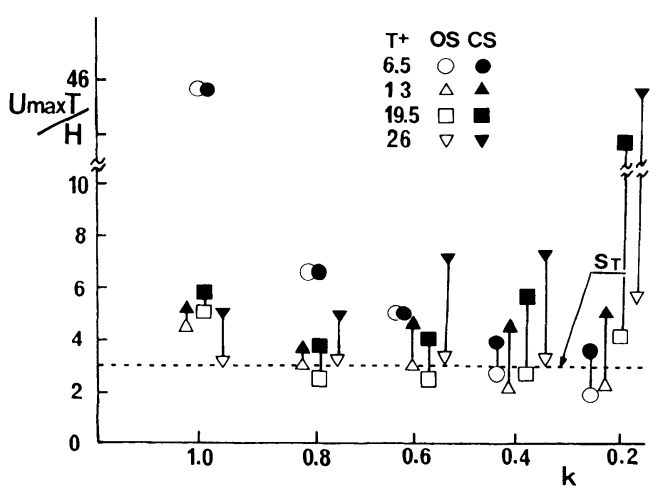

Fig. 10 Average burst periods as $T^{+}, k$ is changed.

以上の Fig. 9, Fig. 10 の結果から, VITA 法における 最適パラメーターを决定する際には, 可視化の形象亡流 速波形の 1 対 1 の対応を明確にすることが必要と思われ る.

\section{4. 結 論}

横断面可視化と流速計測の同時併用によって, 壁縦渦 構造亡 $U, V$ 成分の流速変動波形の対応が詳細に検討 され, 壁縦渦の空間的挙動とその配置特性が流速変動の 形成にきわめて重要な役割を果たすことが明らかにされ た.また, 本同時併用の結果をもとに, VITA 法におけ 
る最適パラメーターの決定方法についても考察が加えら れた。以下に，本論の主要な結論を示す。

（1）壁緥渦の横断面形象亡流速変動波形は, 1 対 1 で対応し，低・高速の変動波形のパターンは，流速計測 点亡壁縦渦の相対的位置関係によって区別され得る．す なわち, 壁縦渦の中央部分とその付根の領域 ( $\mathrm{M}, \mathrm{N}$ 領 域）で上昇流が，壁緹渦の周辺領域（L領域）において 下降流が形成される.

（2）壁縦渦構造およびその配置特性に対応する特徵

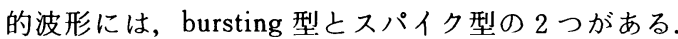
bursting 型波形は，壁縦渦のいくつかが集中した領域を 計測点が通過する際に形成され，比較的小規模の秩序構 造の集団が，長周期の波形を造り出すこともあり得る.

またスパイク型波形は，壁縦渦を構成するそれぞれの渦 対同士が互いに横方向に摇動する際に形成される.

（３）VITA 法における最適パラメーターを決定する 際には, 可視化の形象と流速波形の相互関係を明らかに することが必要であり，それを踏まえて $T^{+}=13, k=$ 0.8 が得られた.

\section{参 考 文 献}

1) Kline, S. J. : The role of visualization in the study of the turbulent boundary layer, Lehigh Workshop on Coherent Structure of Turbulent Boundary Layers, pp. 1 26, 1978.

2）大成博文 - 佐賀孝徳 - 山本恭子 - 斎藤 隆：開水路乱流 の可視化と流速計測の同時併用 (2), 第 30 回水理講演 会論文集，pp. 577～582，1986.

3）佐賀孝徳 - 大成博文・斎藤 隆：壁乱流内層の可視化と 流速計測の同時併用，第 18 回乱流シンポジウム講演論文 集, pp. 95 101, 1986.

4）佐藤 浩：乱れの中の秩序, 乱流現象の解明之制御 中 津川研究成果報告集, pp. 1 12, 1981.

5) 中川博次 : 乱流研究の展望と今後の課題, 土木学会論文 集, 第 351 号 /II-2, pp. 29 40, 1984.

6) Head, M. R. and Bandyopadhyay, P. : Combined flow visualization and hot-wire measurements in turbulent boundary layers, Lehigh Workshop on Coherent Structure of Turbulent Boundary Layers, pp. 98 129, 1978.

7) Falco, R. E. : The role of outer flow coherent motions in the production of turbulence near a wall, Lehigh Work shop on Coherent Structure of Turbulent Boundary Layers, pp. 448 461, 1978.

8) Falco, R. E. : The production of turbulence near a wall, AIAA 13th Fluid \& Plasma Dynamics Conference, pp. 1 $\sim 11,1980$.

9) Bogard, D. G. and Tiederman, W. G. : Burst detection with single-point velocity measurements, J. Fluid Mech., Vol. 162, pp. 389 413, 1986.

10）大成博文・佐賀孝徳・山本恭子・斎藤 隆：壁面領域内 乱流構造の比較可視化，流れの可視化，Vol. 4, No. 12, pp. $47 \sim 54,1984$.

11）大成博文・佐賀孝徳 - 斎藤 隆：壁面領域内乱流構造の 立体的可視化，土木学会論文集，第 345 号 /II-1，pp. 63 $\sim 71,1984$.

12) Kim, H. T., Kline, S.J. and Reynolds, W. C. : The production of turbulence near a smooth wall in a turbulent boundary layer, J. Fluid Mech., Vol. 50 part 1, pp. 133 $\sim 160,1971$

13）大成博文 - 佐賀孝徳 - 斎藤 隆：開水路乱流の可視化と 流速計測 $の$ 同時併用, 第 28 回水理講演会論文集, pp. $213 \sim 218,1984$.

14）大成博文・佐賀孝徳・斎藤 隆：開水路乱流内層の縦渦 構造, 土木学会論文集, 第 363 号 /II-4, pp. 135 144, 1985.

15）中川博次・爾津家久・富永晃宏：開水路流れにおける横 断方向の縞構造と大規模乱流，土木学会論文報告集，第 312 号, pp. 93 105, 1981

16）大成博文・佐賀孝徳・渡辺勝利・斎藤 隆：壁乱流内層 の秩序構造のラグランジュ的追跡，第 19 回乱流シンポジ ウム講演論文集，pp. 205～209，1987.

17）大成博文・佐賀孝徳・斎藤 隆：開水路乱流における秩 序運動の相互作用過程, 第 28 回水理講演会論文集, pp. 233 238, 1984.

18) Blackwelder, R.F. and Kaplan, R.E. : On the wall structure of the turbulent boundary layer, J. Fluid Mech., Vol.76, part 1, pp.89 112, 1976.

(1987.12.10 • 受付) 